\title{
FLOW-LAW PARAMETERS OF THE DYE 3, GREENLAND, DEEP ICE CORE
}

\author{
by
}

\author{
H. Shoji and C.C. Langway $\mathrm{Jr}$
}

(Department of Geological Sciences, State University of New York at Buffalo, 4240 Ridge Lea Road, Amherst, NY 14226, U.S.A.)

\begin{abstract}
Uniaxial compression tests under constant crosshead speed were carried out on 22 new specimens from the 268, 1890,1944 and $2006 \mathrm{~m}$ depths of the Dye 3, Greenland, ice core. The measurements were made in a laboratory cold-room, using an Instron model 1131 apparatus. Test temperatures were held constant between $-17^{\circ}$ and $-13^{\circ} \mathrm{C}$, the approximate sample in-situ temperature. Specimens were prepared with various test orientations in relation to the long vertical core axis. The specimens were analyzed in terms of the content of dust, $\mathrm{Cl}^{-}, \mathrm{NO}_{3}{ }^{-}$and $\mathrm{SO}_{4}{ }^{2-}$ concentrations and various other physical parameters, such as ultrasonic wave velocities, $c$-axis orientation patterns and grain-size. The results of the previous uniaxial compression tests show that most of the flow occurs in the Wisconsin-age ice between $1786 \mathrm{~m}$ and the bottom of the ice sheet. This entire depth interval is strongly anisotropic, with a vertical $c$-axis fabric pattern. The enhancement factor, E, which was calculated from these tests ranges from 0.03 to 17. The Wisconsin-age ice is about ten times softer $\left(E_{S}=10\right)$ than artificially made laboratory ice $(E=1)$. The combined results of the multi-parameter correlation analyses show that $\mathrm{E}$ is controlled primarily by the orientation strength of $c$-axes and that the impurity concentration-level variations contribute to a lesser degree.
\end{abstract}

\section{INTRODUCTION}

The flow behavior of polycrystalline polar ice is determined by factors inherent in the material itself and influenced by the unique characteristics of the site location. The proper construction of a time-scale for a deep ice core requires knowledge of the mechanical properties of the ice at the drill site as well as in the vicinity and up-stream of the drill site. The main objective of this study was to measure the deformational response of actual ice-core samples to applied stresses and to quantify these responses in terms of a flow law. The fact that ice cores relax after removal from their confining stress environment complicates the laboratory tests and requires full awareness of the transport and storage history of the test specimens, and the time-dependent changes in their physical properties. Of prime importance in the study was the measurement of various other physical and chemical parameters of the core samples before and after mechanical testing to investigate their influence on the behavior of the material. It is the total physical and chemical character of the ice-core samples, and the natural environmental variations existing within them, that define the material properties of the specimens tested.

Control data on the mechanical characteristics of fresh samples were initially obtained immediately after the Dye 3 core lengths were recovered in the field, during 1980 and 1981 (Shoji and Langway 1985[a]). These studies were critical to understanding the "aging effect" of deep ice cores. Since then, additional detailed laboratory tests and measurements have been made on sample sets obtained from ice adjacent to the original specimens and at many other levels selected over the entire $2037 \mathrm{~m}$ profile at Dye 3 (Shoji and Langway 1985[b]). The earlier results were analyzed using the power-law creep equation and gave stress-exponent values ranging from 2.7 to 3.2 . These values are in close agreement with the 3.0 exponent value obtained by Barnes and others (1971) on laboratory-made polycrystalline ice. Results of the Dye 3 ice-core studies indicate that the flow law of glacier ice is

$$
\dot{\varepsilon}=\mathrm{E}_{\mathrm{S}} \mathrm{A} \sigma^{\mathrm{n}} \exp (-\mathrm{Q} / \mathrm{RT})
$$

where

$$
\left.\mathrm{E}_{\mathrm{S}}=\dot{\varepsilon} \text { meas./[A } \sigma^{\mathrm{n}} \exp (-\mathrm{Q} / \mathrm{RT})\right]
$$

$\dot{\varepsilon}$ is the uniaxial strain-rate, $\sigma$ is the maximum uniaxial stress, $R$ is the gas constant and $T$ is the absolute temperature. The constants $\mathrm{A}, \mathrm{n}$ and $\mathrm{Q}$ are those of Barnes and others (1971), and $E_{S}$ is the strain-rate enhancement factor for horizontal shear deformation obtained from our test results on the Dye 3 ice core by using Equation 2. For shear deformation tests the long axis of the test specimens was oriented and cut $45^{\circ}$ from the vertical long-core axis. The experimental results give values of $E_{S}$ ranging from 0.1 to 17. The average value of $E_{S}$ is 0.5 at shallow depth and gradually increases towards the bottom. The Wisconsin-age ice, below $1786 \mathrm{~m}$ depth in the core, is about ten times softer $\left(E_{S}=10\right)$ than laboratory-made ice $\left(E_{S}=1\right)$. The ice-core results agree favorably with Dye 3 bore-hole-tilt measurements made in the field (Gundestrup and Hansen 1984, Dahl-Jensen 1985). Russell-Head and Budd (1979) interpreted their bore-hole-tilt measurements in terms of $c$-axis fabric patterns. Gundestrup and Hansen (1984) and Fisher and Koerner (1986) interpreted their results in terms of the strong correlation between bore-hole-tilt, closure measurements and dust-concentration levels. Shoji and Langway (1984) took into account both fabric patterns and impurity-level effects and calculated an enhancement-factor profile for Dye 3 .

In order to investigate further the parameters that influence the enhancement-factor term, $E_{s}$, new experiments were carried out on the Dye 3 ice core. The new experiments were planned to test the genera enhancement-factor term, E. This was done by preparing specimens which had various orientations in relation to the vertical long-core axis. Where

$$
E=E(\theta)
$$

$\theta$ is the angle between the uniaxial stress direction and the vertical long-core axis. The numerical value of $E$ was calculated by using Equation 2. $\mathrm{E}=\mathrm{E}_{\mathrm{S}}$ when the specimen is prepared with angle, $\theta$, equal to $45^{\circ} . E=E_{S}=1$ for randomly oriented laboratory polycrystalline ice.

\section{SAMPLES AND MEASUREMENTS}

This investigation was designed to separate the effects of $c$-axis orientation patterns and impurity-concentration levels on flow behavior and, if possible, to identify the dominant parameters. Two sets of samples were carefully selected for this study. One set was a continuous, unfractured $68 \mathrm{~cm}$ length of core from the $268 \mathrm{~m}$ depth; the other consisted of three unfractured $50 \mathrm{~cm}$ length core pieces from the 1890,1944 and $2006 \mathrm{~m}$ depths. Important paleo-environmental information and other useful data were already available for these samples, which (along with their 
excellent physical condition) influenced their selection for further investigation.

We knew from the $\delta^{18} \mathrm{O}$ record (Reeh and others 1985) that the approximate age for the $268 \mathrm{~m}$ sample was about A.D. 1500 and that the general level of ionic impurities for this sample was approximately the background value (M.M. Herron and Langway 1985). This $68 \mathrm{~cm}$ interval represents approximately a 2 year period. We also knew that the core sample was located in the zone of random $c$-axis orientation (S.L. Herron and others 1985). The three deeper ice-core samples had similar supplementary information associated with their position in the Dye 3 ice-core column. For example, they were all located in the early to mid-Wisconsin-age ice (Dansgaard and others 1985). The 1890 and $1944 \mathrm{~m}$ core samples were deposited as snow approximately 40 and $70 \mathrm{ka}$ B.P. respectively. The $2006 \mathrm{~m}$ core sample probably formed close to the Wisconsin/Sangamon transition and is just above the near-bottom silty ice zone.

The $268 \mathrm{~m}$ core sample was first re-examined and photographed on a light-table. A detailed megascopic inspection was made in order to record the microstratigraphy. Scattered-light intensity was continuously measured on the microtomed surface by transmitting a beam of white light, perpendicular to the optic-cell receiver, through the core. Crystal size was measured by observing evaporated crystal-boundary grooves on the planar microtomed surface and by measuring linear intercepts; no correction was made for the raw values. The core sample was then cut, perpendicular to its long axis, into seven individual specimens. After ultrasonic wave velocity was measured along, and perpendicular to, the long-core axis, a uniaxial compression test under constant crosshead speed was performed on each specimen $(2.5 \times 2.5 \times 9.2 \mathrm{~cm})$. Stress was applied in a direction parallel to the long-core axis $\left(\theta=0^{\circ}\right)$. Specimens adjacent to the test pieces were prepared for chemical analysis by trimming and flushing under clean-room conditions; they were then melted in sterile polypropylene containers in a microwave oven and measured for $\mathrm{NO}_{3}{ }^{-}, \mathrm{Cl}^{-}$and $\mathrm{SO}_{4}{ }^{2-}$, using an ion chromatograph and following procedures described earlier (M.M. Herron and Langway 1985, Finkel and Langway 1985). The dust content and $\delta^{18} \mathrm{O}$ of the core samples were measured at the University of Copenhagen by Dansgaard and co-workers (unpublished).

A total of seven specimens was prepared for mechanical tests from the $1890 \mathrm{~m}\left(\theta=0^{\circ}-90^{\circ}\right)$ and $1944 \mathrm{~m}$ $\left(\theta=90^{\circ}\right)$ samples. Eight specimens from the $2006 \mathrm{~m}$ sample were prepared for mechanical tests $\left(\theta=0^{\circ}-90^{\circ}\right)$. Ultrasonic wave velocity was measured along the stress direction on all deep specimens before and after mechanical testing. The chemical and dust content of the specimens was obtained from the general curves (Hammer and others 1985, Langway and Goto-Azuma 1988, this volume).

Uniaxial compression tests were made using an Instron model 1131 apparatus. Ultrasonic P-wave velocity was measured using a Krautkramer-Branson USL 38 instrument with a $2.25 \mathrm{MHz}$ transducer and a silicone oil couplant. Temperature control for the compression tests was better than $\pm 0.5^{\circ} \mathrm{C}$. All experiments were performed in a cold-room laboratory, where temperatures were held constant between $-17^{\circ}$ and $-13^{\circ} \mathrm{C}$ in order to approximate the in-situ temperature conditions.

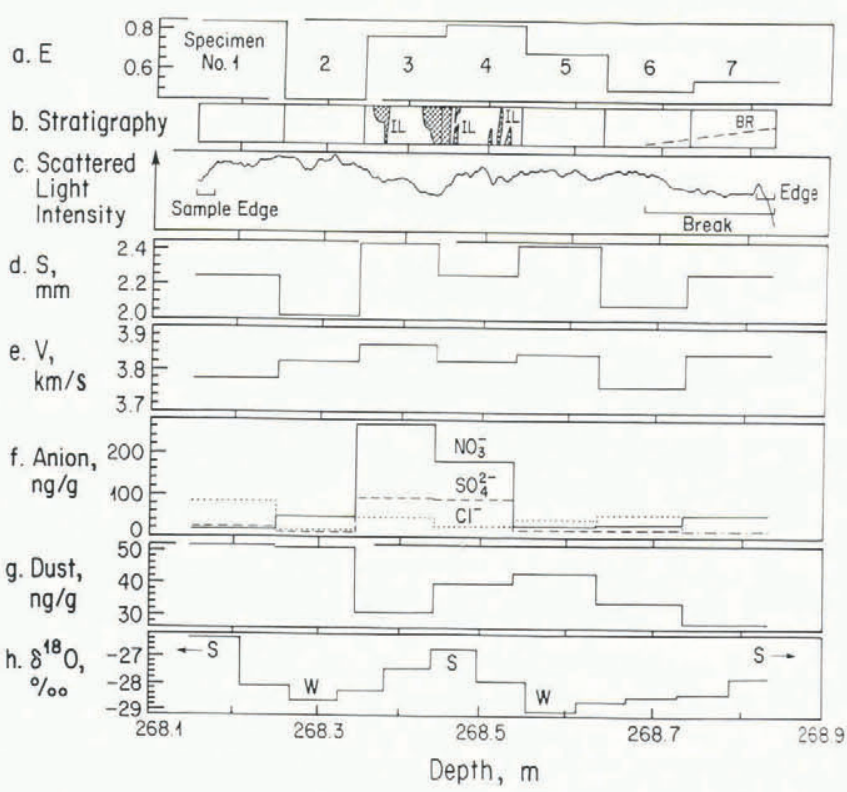

Fig.1. Experimental tests and detailed measurements on the $268 \mathrm{~m}$ sample. The sample was cut into seven specimens for mechanical testing purposes, and various other sizes or sections for the other properties listed in the left-hand column.

\section{RESULTS AND DISCUSSION}

The experimental test and measurement data from the $268 \mathrm{~m}$ sample specimens are summarized in Figure 1 and listed in Table I. Figure 1b shows the main stratigraphic features of the core samples; the up-direction is to the left Note the pronounced ice layers and lenses (IL) located near the center of Figure $\mathrm{Ib}$ and stratigraphically just above the $\delta^{18} \mathrm{O}$ summer peaks as shown in Figure $1 \mathrm{~h}$. This suggests that melt from a succeeding warm summer percolated downward and enhanced the thicknesses of previously existing lower and thinner ice layers. This interpretation explains the large anion peaks (If) which are stratigraphically coincident with the ice layers. The detailed chemistry results are shown in Figure 2, where the correlation is much clearer. Both the ice layers and the chemistry peaks are slightly out of phase with the $\delta^{18} \mathrm{O}$ curve. The scattered-light intensity measurements (1c) agree in general with the ice-layer features. This occurs because when the melt which makes up the mass of the ice layers refreezes, it tends to exclude or suppress air-bubble re-formation, resulting in reduced light scatter. Figure 1d shows average crystal size, S, for the seven specimens. Size ranges from 2.0 to $2.4 \mathrm{~mm}$. The ultrasonic wave velocity, which was measured along the long-core axis, is shown in Figure le. The range in velocity is in agreement with other data between the 200 and $600 \mathrm{~m}$ depths (S.L. Herron and others 1985) and reflects the existence of random-oriented $c$-axis fabric patterns. The dust-concentration levels $(1 \mathrm{~g})$ are relatively low, ranging

TABLE I. RESULTS OF UNIAXIAL COMPRESSION TESTS ON $268 \mathrm{~m}$ DEPTH SPECIMENS. EACH SPECIMEN WAS DEFORMED TO ABOUT 5\% UNIAXIAL STRAIN.

$\begin{array}{cccccc}\begin{array}{c}\text { Core tube number } \\ \text { (Specimen number) }\end{array} & \begin{array}{c}\text { Depth } \\ \mathrm{m}\end{array} & \begin{array}{c}\text { Temperature } \\ { }^{\mathrm{C}}\end{array} & \begin{array}{c}\text { Maximum } \\ \text { stress } \\ \text { bar }\end{array} & \begin{array}{c}\text { Strain- } \\ \text { rate } \\ \times 10^{-7} \mathrm{~s}^{-1}\end{array} & \begin{array}{c}\text { Enhancement } \\ \text { factor } \\ \text { (E) }\end{array} \\ 188 / 1 & 268 & -12.6 & 12.3 & 1.8 & 0.84 \\ 188 / 2 & 268 & -12.5 & 14.0 & 1.4 & 0.45 \\ 188 / 3 & 268 & -12.7 & 12.7 & 1.8 & 0.77 \\ 188 / 4 & 268 & -12.7 & 12.4 & 1.8 & 0.83 \\ 188 / 5 & 268 & -12.8 & 13.1 & 1.7 & 0.68 \\ 188 / 6 & 268 & -12.6 & 14.2 & 1.6 & 0.50 \\ 188 / 7 & 268 & -12.5 & 14.1 & 1.8 & 0.55\end{array}$




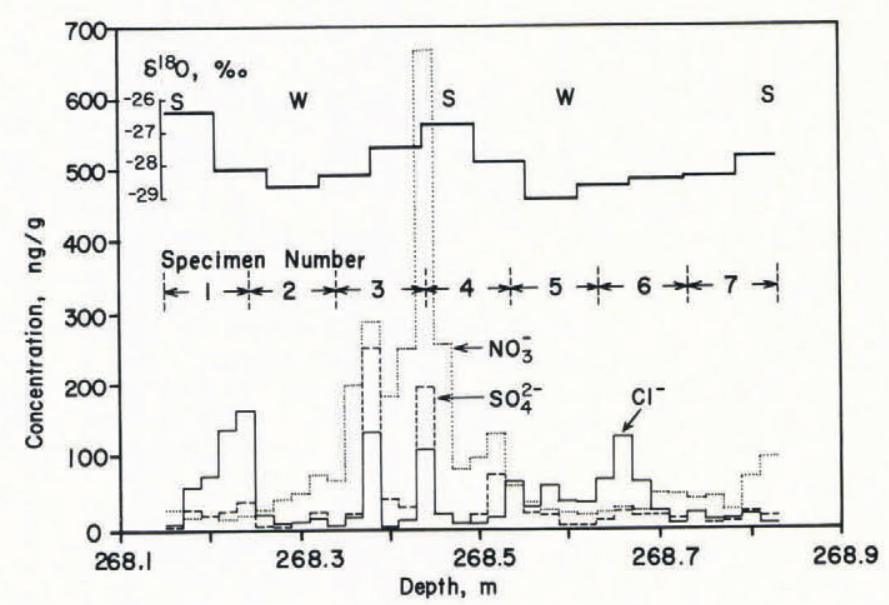

Fig.2. Detailed chemistry measurements from the $268 \mathrm{~m}$ sample. Thirty-four specimens were measured for $\mathrm{Cl}^{-}$ (solid line) $\mathrm{NO}_{3}{ }^{-}$(dotted line) and $\mathrm{SO}_{4}{ }^{2-}$ (broken line), and compared with $\delta^{18} \mathrm{O}$ measurements by Dansgaard and co-workers (unpublished).

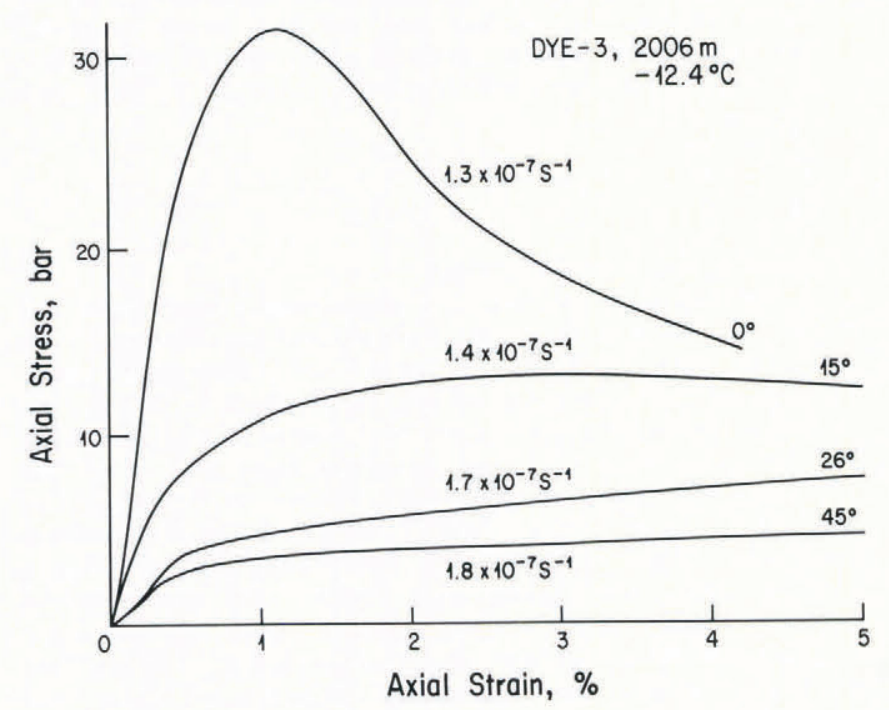

Fig.3. Stress-strain relationship of the $2006 \mathrm{~m}$ sample specimens. Uniaxial stress direction, $\theta$, ranges from $0^{\circ}$ to $45^{\circ}$ from the vertical long-core axis. Strain-rate values are given above or below each curve. from 27 to $52 \mathrm{ng} / \mathrm{g}$, compared with the Wisconsin-age ice dust range of between 100 and $3000 \mathrm{ng} / \mathrm{g}$. Figure la shows specimen numbers and the amplitude of the enhancement-factor values, E, calculated for the seven specimens. $E\left(0^{\circ}\right)$ ranges from 0.45 to 0.84 . This value is similar to the values reported ealier for the $247 \mathrm{~m}$ depth (Shoji and Langway 1985[b]), where stress was applied to the specimens in a direction $45^{\circ}$ inclined to the long-core axis $\left(E_{S}\right)$.

Table II lists the results of the uniaxial compression tests on the 1890, 1944 and $2006 \mathrm{~m}$ specimens. Figures 3 and 4 show the strong anisotropy in the stress-strain curves for the $2006 \mathrm{~m}$ specimens. Measured strain-rate values range from $1.3 \times 10^{-7}$ to $2.9 \times 10^{-7} \mathrm{~s}^{-1}$. Large yields are shown for the flow-stress data when stresses are applied parallel to $\left(\theta=0^{\circ}\right)$ or perpendicular to $\left(\theta=90^{\circ}\right)$ the long-core axis.

Figure 5 shows a plot of the stress-application direction, $\theta$, versus the calculated enhancement factor, $E(\theta)$, for each test run for all of the fifteen Wisconsin-age ice samples in this study. Results from our previous experiments on the $45^{\circ}$ stress direction are also included in Figure 5 (Shoji and Langway 1985[b]). The horizontal dashed line, BTW, represents the $\mathrm{E}$ value $(=1)$ for randomly oriented laboratory ice (Barnes and others 1971). It is noted that the

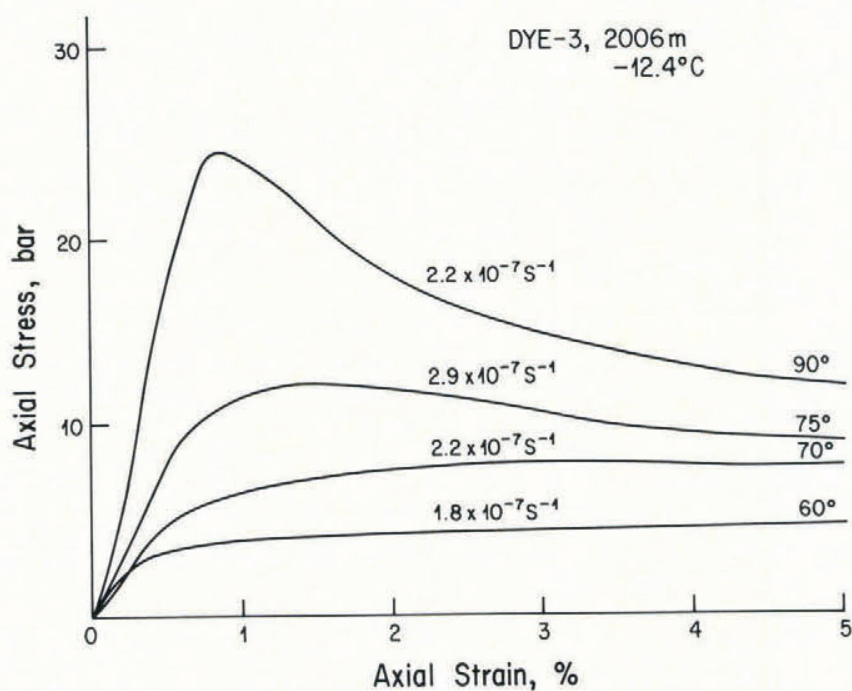

Fig.4. Stress-strain relationship of the $2006 \mathrm{~m}$ sample specimens. Uniaxial stress direction, $\theta$, ranges from $60^{\circ}$ to $90^{\circ}$ from the vertical core axis. Strain-rate values are given above each curve.

TABLE II. UNIAXIAL COMPRESSION TEST RESULTS OF 1890, 1944 AND $2006 \mathrm{~m}$ DEPTH SPECIMENS. EACH SPECIMEN WAS DEFORMED TO ABOUT 5\% UNIAXIAL STRAIN.

\begin{tabular}{|c|c|c|c|c|c|c|}
\hline $\begin{array}{l}\text { Core tube } \\
\text { number } \\
\text { (Specimen } \\
\text { number) }\end{array}$ & $\begin{array}{l}\text { Depth } \\
\text { m }\end{array}$ & $\begin{array}{c}\text { Temperature } \\
{ }^{\circ} \mathrm{C}\end{array}$ & $\begin{array}{l}\text { Maximum } \\
\text { uniaxial } \\
\text { stress } \\
\text { bar }\end{array}$ & $\begin{array}{l}\text { Uniaxial } \\
\text { strain- } \\
\text { rate } \\
\times 10^{-7} \mathrm{~s}^{-1}\end{array}$ & $\begin{array}{l}\text { Applied } \\
\text { stress } \\
\text { direction } \\
\text { degree from } \\
\text { core axis }\end{array}$ & $\begin{array}{l}\text { Enhancement } \\
\text { factor } \\
\text { (E) }\end{array}$ \\
\hline $1840 / 1$ & 1890 & -12.5 & 30.7 & 1.5 & 0 & 0.04 \\
\hline $1840 / 2$ & 1890 & -12.5 & 27.2 & 1.9 & 15 & 0.08 \\
\hline $1840 / 3$ & 1890 & -12.6 & 17.4 & 1.8 & 30 & 0.29 \\
\hline $1840 / 4$ & 1890 & -12.4 & 17.8 & 1.6 & 90 & 0.24 \\
\hline $1840 / 5$ & 1890 & -12.5 & 16.6 & 1.9 & 90 & 0.36 \\
\hline $1894 / 1$ & 1944 & -12.5 & 19.1 & 1.9 & 90 & 0.24 \\
\hline $1894 / 2$ & 1944 & -12.2 & 18.6 & 2.0 & 90 & 0.26 \\
\hline $1957 / 1$ & 2006 & -12.5 & 31.7 & 1.3 & 0 & 0.03 \\
\hline $1957 / 2$ & 2006 & -12.5 & 13.0 & 1.4 & 15 & 0.56 \\
\hline $1957 / 3$ & 2006 & -12.5 & 8.1 & 1.7 & 26 & 2.8 \\
\hline $1957 / 4$ & 2006 & -12.6 & 5.0 & 1.8 & 45 & 13 \\
\hline $1957 / 5$ & 2006 & -12.5 & 4.5 & 1.8 & 60 & 17 \\
\hline $1957 / 6$ & 2006 & -12.4 & 7.8 & 2.2 & 70 & 3.9 \\
\hline $1957 / 7$ & 2006 & -12.4 & 12.1 & 2.9 & 75 & 1.4 \\
\hline $1957 / 8$ & 2006 & -12.4 & 24.6 & 2.2 & 90 & 0.13 \\
\hline
\end{tabular}


TABLE III. PHYSICAL AND CHEMICAL CHARACTERISTICS OF TEST SAMPLES.

$\begin{array}{cccclclccc}\begin{array}{l}\text { Sample } \\ \text { number }\end{array} & \begin{array}{l}\text { Sample } \\ \text { depth }\end{array} & \begin{array}{c}\text { Ice } \\ \text { fabrics }\end{array} & \begin{array}{l}\mathrm{Cl}^{-} \\ \mathrm{ng} / \mathrm{g}\end{array} & \begin{array}{l}\mathrm{NO}_{3}{ }^{-} \\ \mathrm{ng} / \mathrm{g}\end{array} & \begin{array}{l}\mathrm{SO}_{4}{ }^{2-} \\ \mathrm{ng} / \mathrm{g}\end{array} & \begin{array}{l}\text { dust } \\ \mathrm{ng} / \mathrm{g}\end{array} & \begin{array}{c}\text { Grain- } \\ \text { size } \\ \mathrm{mm}\end{array} & \begin{array}{c}\theta \\ \text { degree }\end{array} \\ 1 & 268 & \mathrm{R} & 15-85 & 20-271 & 12-94 & 27-52 & 2.0-2.4 & 0 \\ 2 & 1485 & \mathrm{VC} & 18-28 & 57-67 & 22-32 & - & 3-9 & 45 \\ 3 & 1659 & \mathrm{SM} & 15-25 & 49-59 & 23-37 & 95-115 & 3-7 & 45 \\ 4 & 1759 & \mathrm{SM} & 17-35 & 47-57 & 21-79 & 95-115 & 3-7 & 45 \\ 5 & 1806 & \text { SSM } & 43-53 & 41-51 & 47-57 & 130-176 & 1.4-1.7 & 45 \\ & & & & & & & & \\ 6 & 1851 & \text { SSM } & 91-101 & 35-45 & 117-191 & 1550-2850 & 0.6-1.0 & 45 \\ 7 & 1890 & \text { SSM } & 43-67 & 34-52 & 29-83 & 800-1200 & 0.5-1.3 & 0-90 \\ 8 & 1930 & \text { SSM } & 42-80 & 36-52 & 51-101 & 175-195 & 0.9-1.5 & 45 \\ 9 & 1944 & \text { SSM } & 40-50 & 32-42 & 23-33 & 215-265 & 1.4-1.6 & 45-90 \\ 10 & 1972 & \text { SSM } & 22-32 & 30-42 & 46-56 & 185-205 & 1.9-2.1 & 45 \\ & & & & & & & & \\ 11 & 2006 & \text { SSM } & 29-29 & 41-51 & 30-40 & 195-215 & 1.9-2.3 & 0-90\end{array}$

Note: For this table, impurity levels and grain-sizes were measured (sample no.1) or estimated (sample nos.2-11) by using the data of S.L. Herron and others (1985), Langway and Goto-Azuma (1988, this volume) and Hammer and others (1985). Ice-fabric studies were made by S.L. Herron and others (1985); R is random-orientation fabric, VC is vertical cluster, SM is single maximum and SSM is strong single maximum.

enhancement factor is quite sensitive to the stress direction and varies by more than two orders of magnitude. The $\theta$ dependency of $\mathrm{E}$ can be interpreted in terms of the resolved shear stress along the crystal basal plane perpendicular to each $c$-axis. The resolved shear stress has a maximum value when the crystal basal plane (slip plane) is inclined $45^{\circ}$ from the stress direction. Since a dislocation glide motion is driven by the resolved shear stress, ice crystals produce the highest strain-rate when $\theta=45^{\circ}$, resulting in a maximum enhancement-factor value. Table III lists all the various physical and chemical parameter measurements for specimens used in this study. As shown,

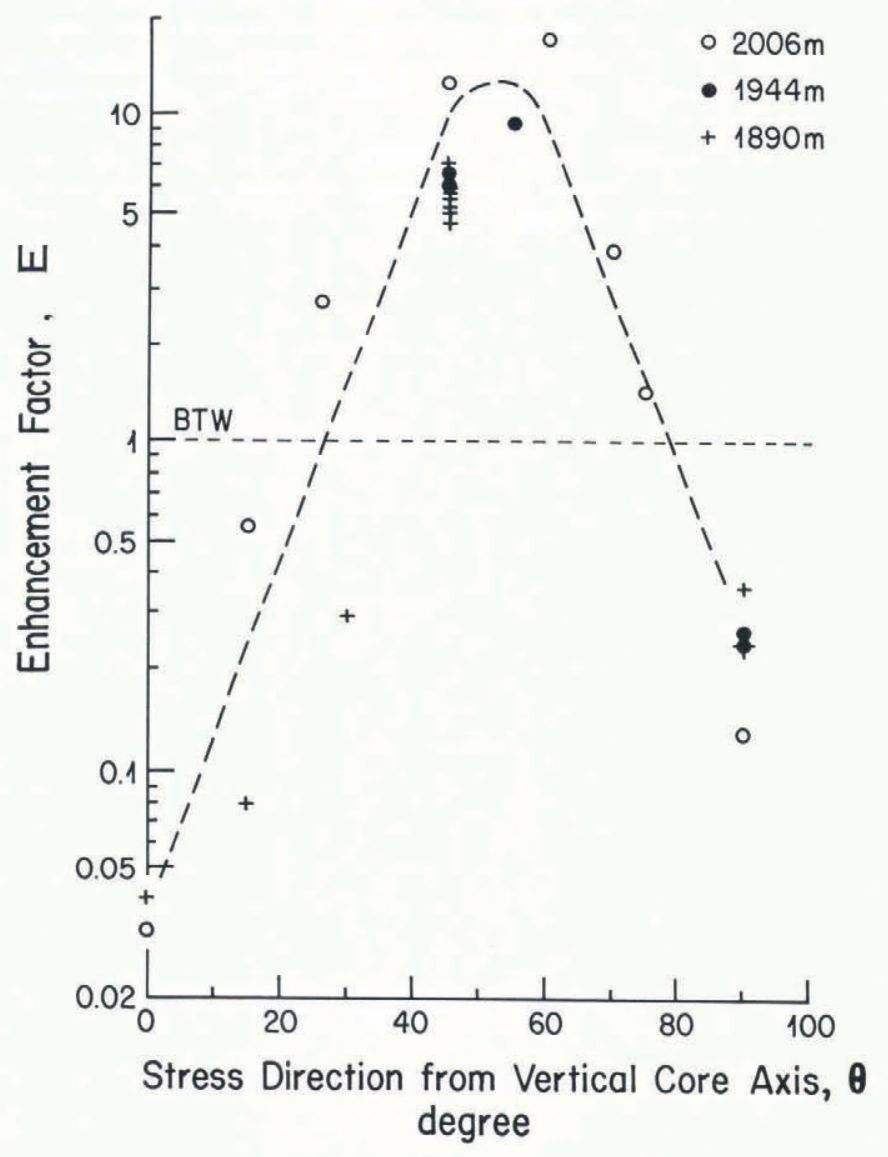

Fig.5. Enhancement factor, E, versus stress direction, $\theta$, for the 1890,1944 and $2006 \mathrm{~m}$ samples. the dust content for the $1890 \mathrm{~m}$ sample is three-five times higher than that of the 1944 and $2006 \mathrm{~m}$ samples. If dust has a softening effect, the $E(\theta)$ curve for the $1890 \mathrm{~m}$ depth sample (Fig.5) should increase to higher $\mathrm{E}$ values compared to the other two samples. However, Figure 5 shows no such trend and it is concluded that the dust effect is small when compared with the $c$-axis orientation effect.

Figure 6 is a plot of ultrasonic wave-velocity measurements made on each specimen before the uniaxial testing, as shown in Table III. The ultrasonic velocity was measured along the longest dimension of each specimen, i.e. parallel to the uniaxial stress direction. The lower velocity values indicate that the pole direction of $c$-axis orientations is inclined closer to $45^{\circ}$ from the wave-propagation direction. The higher velocity values indicate the pole direction is inclined nearer to parallel or perpendicular to the wave-propagation direction (Langway and others 1988, this volume). The inverse correlation between the velocity and the enhancement factor is clear in this semi-log plot.

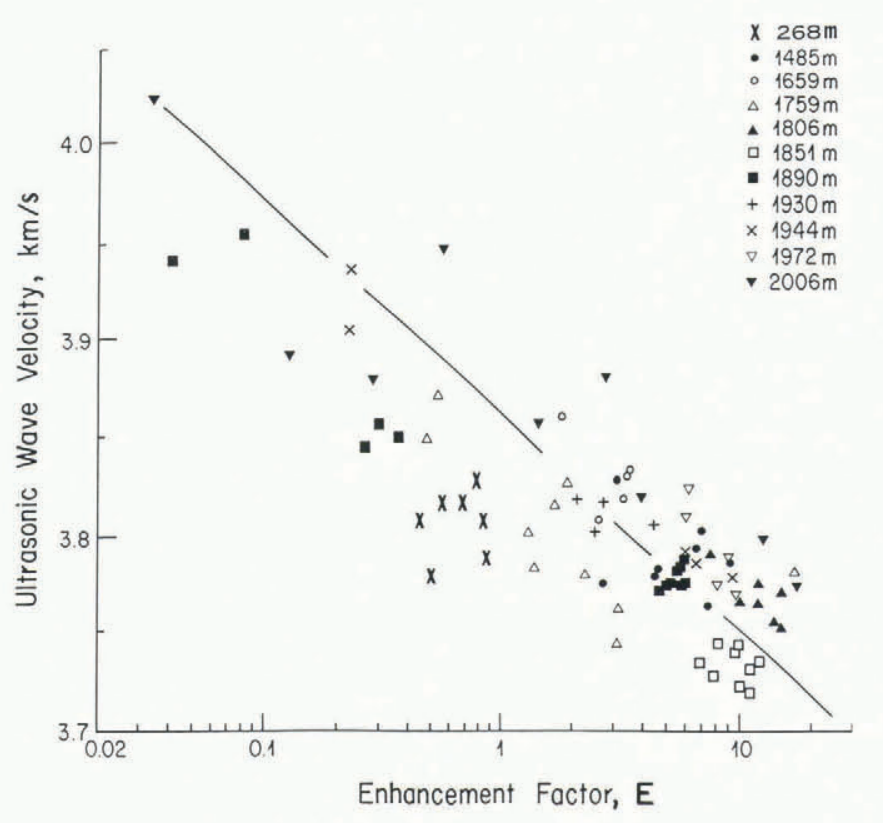

Fig.6. Ultrasonic wave-velocity measurements versus calculated enhancement-factor values for all specimens discussed in this study. Sample depth ranges from 268 to $2006 \mathrm{~m}$. 
This trend can be interpreted in terms of the resolved shear stress as discussed above. The data points of the $268 \mathrm{~m}$ sample show slight deviations from all other data points shown in Figure 5. The results of the high dust-content samples from 1851 and $1890 \mathrm{~m}$ (Table III) do not show a clear softening effect (higher $\mathrm{E}$ values) when compared with other data points from the depth interval between 1485 and $2006 \mathrm{~m}$. The $c$-axis orientation fabrics of the $268 \mathrm{~m}$ sample are randomly oriented, whereas the $1485-2006 \mathrm{~m}$ samples have vertically preferred $c$-axis orientations which are classified as vertical- cluster, single-maximum or strong single-maximum (Table III). The deviation of the $268 \mathrm{~m}$ data is probably a result of variations in the type of the fabric pattern.

The regression line for 1485-2006 m depth data shown in Figure 5 is calculated by least squares as

$$
\mathrm{E}=7.6 \times 10^{34} \exp (-20.8 \mathrm{~V})
$$

where $\mathrm{E}$ is the strain-rate enhancement factor obtained by Equation 2 and $V$ is the ultrasonic wave velocity in $\mathrm{km} / \mathrm{s}$. This empirical relationship (Equation 4) is used to interpret the deformational response of the Dye 3 samples below $1485 \mathrm{~m}$ to the uniaxial compression stresses, by taking into consideration the ice-fabric effect. By using Equation 4, the enhancement factor values of $E_{S}\left(=E\left(45^{\circ}\right)\right)$ can be calculated from the ultrasonic velocities measured in a direction inclined $45^{\circ}$ to the vertical long-core axis, which behave in an opposite way to the horizontal- or vertical-velocity changes.

\section{CONCLUSION}

The flow law for polar ice is best described by the general enhancement factor, $E$, which is a function of $c$-axis orientation patterns. These $c$-axes can rapidly be determined, using a new semi-automiatic ultrasonic wave-velocity measuring device. An impurity softening effect by $\mathrm{Cl}^{-}, \mathrm{NO}_{3}{ }^{-}, \mathrm{SO}_{4}{ }^{2-}$ or dust was not observed to influence strongly the mechanical test results within the limits of this study. Consequently these findings indicate that $c$-axis orientation is the prime parameter for shear deformation below $1786 \mathrm{~m}$ at Dye 3, Greenland, but that more studies of the $c$-axis re-orientation process are required.

\section{ACKNOWLEDGEMENTS}

This work was supported by the U.S. National Science Foundation, Division of Polar Programs, grant no. DPP-8520911. We thank Dr W Dansgaard and his co-workers for their unpublished $\delta^{18} \mathrm{O}$ and dust measurements. Chemistry was measured in the laboratory by Carol Clemency.

\section{REFERENCES}

Barnes P. Tabor D, Walker J C F 1971 The friction and creep of polycrystalline ice. Proceedings of the Royal Society of London Ser A 324(1557): 127-155

Dahl-Jensen D 1985 Determination of the flow properties at Dye 3, south Greenland, by bore-hole-tilting measurements and perturbation modelling. Journal of Glaciology 31(108): 92-98

Dansgaard W, Clausen H B, Gundestrup N, Johnsen S J, Rygner C 1985 Dating and climatic interpretation of two deep Greenland ice cores. In Langway C C Jr, Oeschger $\mathrm{H}$, Dansgaard W (eds) Greenland ice core: geophysics, geochemistry and the environment. Washington, DC, American Geophysical Union: 71-76 (Geophysical Monograph 33)

Finkel R C, Langway C C Jr 1985 Global and local influences on the chemical composition of snowfall at Dye 3, Greenland: the record between $10 \mathrm{ka}$ B.P. and 40 ka B.P. Earth and Planetary Science Letters 73(2-4): 196-206

Fisher D A, Koerner R M 1986 On the special rheological properties of ancient microparticle-laden northern hemisphere ice as derived from bore-hole and core measurements. Journal of Glaciology 32(112): 501-510

Gundestrup N S, Hansen B L 1984 Bore-hole survey at
Dye 3, south Greenland. Journal of Glaciology 30(106): 282-288

Hammer C U, Clausen H B, Dansgaard W, Neftel A Kristindottir P, Johnson E 1985 Continuous impurity analysis along the Dye 3 deep core. In Langway C C Jr, Oeschger H, Dansgaard W (eds) Greenland ice core: geophysics, geochemistry and the environment. Washington, DC, American Geophysical Union: 90-94 (Geophysical Monograph 33)

Herron M M, Langway C C Jr 1985 Chloride, nitrate, and sulfate in the Dye 3 and Camp Century, Greenland ice cores. In Langway C C Jr, Oeschger $\mathrm{H}$, Dansgaard W (eds) Greenland ice core: Geophysics, geochemistry and the environment. Washington, DC, American Geophysical Union: 77-84 (Geophysical Monograph 33)

Herron S L, Langway C C Jr, Brugger K A 1985 Ultrasonic velocities and crystalline anisotropy in the ice core from Dye 3, Greenland. In Langway C C Jr, Oeschger H, Dansgaard W (eds) Greenland ice core: geophysics, geochemistry and the environment. Washington, DC, American Geophysical Union: 23-31 (Geophysical Monograph 33)

Langway C C Jr, Goto-Azuma K 1988 Temporal variations in the deep ice-core chemistry record from Dye 3, Greenland. Annals of Glaciology 10: 209

Langway C C Jr, Shoji H, Azuma N 1988 Crystal size and orientation patterns in the Wisconsin-age ice from Dye 3 , Greenland. Annals of Glaciology 10: 109-115

Reeh N, Johnsen S J, Dahl-Jensen D 1985 Dating the Dye 3 deep ice core by flow model calculations. In Langway C C Jr, Oeschger $\mathrm{H}$, Dansgaard W (eds) Greenland ice core: geophysics, geochemistry and the environment. Washington, DC, American Geophysical Union: 57-65 (Geophysical Monograph 33)

Russell-Head D S, Budd W F 1979 Ice-sheet flow properties derived from bore-hole shear measurements combined with ice-core studies. Journal of Glaciology 24(90): $117-130$

Shoji H, Langway C C Jr 1984 Flow behavior of basal ice as related to modeling considerations. Annals of Glaciology 5: 141-148

Shoji H, Langway C C Jr 1985[a] Mechanical properties of fresh ice core from Dye 3, Greenland. In Langway C C $\mathrm{Jr}$, Oeschger $\mathrm{H}$, Dansgaard W (eds) Greenland ice core: geophysics, geochemistry and the environment. Washington, DC, American Geophysical Union: 39-48 (Geophysical Monograph 33)

Shoji H, Langway C C Jr 1985[b] The ice flow velocity profile for Dye-3, Greenland. Geophysical Research Letters 12(12): 797-800 